ks. Anton Tyrol

\title{
Inšpirácia Svätého písma. Komentár k 3. kapitole Dei Verbum
}

Náuku o inšpirácii vo všeobecnosti môžeme označit' za najhlavnejší traktát všeobecnej introdukcie do biblických vied ${ }^{1}$. Autori biblických introdukcií uvádzajú traktát o posvätnom charaktere kníh Písma obyčajne na prvom mieste ${ }^{2}$. Napriek tomu, že magisteriálna definícia bola po prvý raz daná pomerne neskoro, koncom 19. storočia, predsa sa v dejinách krest'anstva venovala tejto téme vždy patričná pozornost'. Možno práve preto bola inšpirácia definovaná až tak neskoro, že jednoducho nebolo potrebné definovat' ju skôr ako v závere osvietenstva či v pokročilom štádiu racionalizmu. Všetky predchádzajúce epochy sa jej však dotýkali aspoň natol'ko, že „obrusovali“ a spresňovali jednotlivé tzv. konštitutívne prvky tejto náročnej teologickej náuky o božskom pôvode a charaktere svätých kníh. Vychádzajúc z textu konštitúcie Dei Verbum vidíme, že náuka o inšpirácii v tejto konštitúcii zaberá celkove tri články (11-13), ktoré zhrnujú to, čo už bolo vyjadrené v predchádzajúcich dobách a rozvijajú túto náuku novými akcentmi a výslovnými explikáciami.

„11. Bohom zjavené pravdy, vo svätom Písme písomne vyjadrené a zachované, boli napísané z vnuknutia Ducha Svätého. Svätá Matka Cirkev má totiž na základe apoštolskej viery za sväté a kánonické knihy Starého a Nového zákona v ich celosti i so všetkými ich čast'ami, pretože napísané z vnuknutia Ducha Svätého (porov. Jn 20, 31; 2 Tim 3, 16; 2 Pt 1, 19-21; 3, 15-16), majú za pôvodcu Boha a ako také boli zverené Cirkvi. Na napísanie posvätných kníh Boh si vyvolil l'udí, ktorých použil tak, že oni uplatnili svoje schopnosti a vlastnosti, účinkujúc on sám v nich a skrze nich, aby napísali ako skutoční pôvodcovia všetko to a len to, čo On sám chcel. Ked’že teda všetko, čo inšpirovaní autori čiže svätopisci tvrdia, treba pokladat' za výrok Ducha Svätého, treba uznat', že knihy Písma bezpečne, verne a bez omylu učia pravdu, ktorú chcel mat' Boh vo svätom Písme zaznačenú na naše spasenie. A teda „každé Písmo, vnuknuté od Boha, je užitočné na poučovanie,

${ }^{1}$ Referat wygłoszony podczas międzynarodowej sesji naukowej dla uczczenia 40. rocznicy soborowej konstytucji Dei Verbum i polskiego przekładu Biblii Tysiąclecia (Kraków, 17 listopada 2005).

${ }^{2}$ Porov. M. TÁBet, P. Gironi, Introduzione generale alla Sacra Scrittura, Roma 1996, s. 1. 
karhanie, naprávanie a vychovávanie v spravodlivosti, aby sa človek Boží stal dokonalým a schopným konat' všetko dobré» (2 Tim 3, 16-17)“.

Logickou štruktúrou tohto 11. článku je schéma vyjadrená v troch bodoch: 1) Boh je autor Písma, 2) Boh inšpiroval l'udských autorov svätých kníh, 3) inšpirované knihy učia pravdu³. Pokial' ide o obsah tohto článku konštitúcie, môžeme v ňom vidiet' na začiatku určitú taxatívnu limitáciu objektu inšpirácie: sú to pravdy vo Svätom písme vyjadrené a zachované. Teda Tradícia podl'a toho nie je predmetom inšpirácie; tá sa vzt'ahuje iba na napísané Božie zjavenie. Zrejme, že Tradícia má svoje iné prvky či garancie neomylnosti, ale inšpirácia ako taká sa vzt'ahuje iba na písané Božie zjavenie. Iste, ani Tradícii ako forme odovzdávaného Božieho zjavenia nechýba prítomnost' Ducha Svätého.

Ďalším prvkom, ktorý tento 11. článok konštitúcie prináša, sú kategórie rozsahu inšpirácie na všetky knihy a na všetky časti Písma (lat. omnia Sacra Scriptura / cum omnibus suis partibus / inspirata est). Sú to kategórie prevzaté z rozhodnutí Tridentského koncilu (EB 60). V d'alšom texte sú potom spomínané kategórie, ktoré sú dôležitou súčast'ou traktátov o inšpirácii: otázka Božieho pôvodu svätých kníh a to, že adresátkou týchto kníh je Cirkev. To je vel'mi významný prvok, ktorý už spomínal pápež Lev XIII. v encyklike Providentissimus Deus r. 1893 (EB 81, 125).

Podstatnými výrazmi, ktorými konštitúcia vniesla istú novost' do náuky o inšpirácii, sú bezpochyby výrazy účinkujúc on sám v nich a skrze nich. V tomto bode je vyjadrený rozsah inšpirácie ešte aj v tom zmysle, že definitívne uzatvára diskusie o formálnom (myšlienky, koncepty... od Boha) a materiálnom elemente (slová... od svätopisca), ktoré svojho času otvoril kardinál J. B. Franzelin. Okrem toho tu nastal výrazný posun, ked' aktívno-pasívny vzt'ah z encykliky Providentissimus Deus bol bližšie objasnený, ba až nahradený aktívno-aktívnym vzt'ahom Boha a svätopisca. V skutočnosti došlo teda k náhrade kategóriíauctor principalis a auctor instrumentalis. Obidve kategórie zaviedol do tejto témy sv. Tomáš Akvinský a táto náuka sa stala klasickou. V koncilovom dokumente Dei Verbum 11 však táto pasáž bola nahradená biblickou formuláciou z $2 \mathrm{Pt}$ 1, 20-21: pod vedením Ducha Svätého prehovorili l’udia poslaní od Boha, ktorá v konštitúcii dostala teologickú explicitáciu. Koncil sa teda nevydal na cestu nejakého exkluzívneho definovania vplyvu Boha či výkonu človeka. Obmedzil sa iba na posilnenie účasti svätopisca. Teda v porovnaní s predchádzajúcimi formuláciami Magistéria autorstvo svätopisca a Boží pôvod kníh Písma boli teraz vyjadrené viac personálnym spôsobom ${ }^{4}$.

\footnotetext{
${ }^{3}$ Porov. ibid., s. 11.

${ }^{4}$ Porov. A. GrillmeIER, Sachliche Exegese von Kapitel III der Konstitution, [in:] Lexikon für Theologie und Kirche, Das zweite vatikanische Konzil, Kommentare II., Freiburg 1967, s. 545.
} 
Kategórie bezpečne, verne a bez omylu učia pravdu predstavujú bližšiu charakteristiku pravdy, ktorá je vyjadrená v Písme. Táto téma bola na koncile pomerne intenzívne diskutovaná, pretože je pomerne t'ažko definovatel'ná. Išlo totiž o odlíšenie náboženskej pravdy od prírodovednej, geografickej, historickej a pod. Koncil sa týmto rozlišovaním bližšie nezaoberal, ale sa vyjadril tak, že bližšie definoval náboženskú pravdu. Preto to konciloví otcovia vyjadrili tak, ako to prináša text konštitúcie: ktorú chcel mat'Boh vo Svätom Písme zaznačenú na naše spasenie. Hned' na prvý pohl'ad vidíme, že Koncil neprehlásil „absolútnu“ neomylnost' Písma, ale „biblickú“ neomylnost': nie je použitý výraz „neomylnost'“, ale jednoducho „pravda“. Výrazy bezpečne a verne (lat. firmiter, fideliter) vyjadrujú zvláštne funkcie Písma, ktoré garantujú istotu človeka a Božiu vernost' zmluve a prísl'ubom daným Božiemu l'udu. Písmo tak nadobúda charakter „reguly viery“. Pokial' ide o tretie sloveso učia, tu sa hlasovalo o spôsoboch namiesto docere bolo možné použit' slovesá exhibere a exprimere, ale nakoniec zostalo sloveso docere, aj ked' znie trochu intelektualisticky, zodpovedá totiž najlepšie biblickej pravde. Definovanie biblickej pravdy týmto spôsobom posunulo celú problematiku na inú rovinu, než ju malo napr. osvietenstvo. Otázka pravdy v Písme sa dnes netýka natol'ko prírodných, geografických a dejinných faktov a iných profánnych právd, ako skôr platnosti pojmu spásy, oprávnenia biblických ideálov a mravných požiadaviek. Predovšetkým o týchto možno tvrdit', že knihy Písma učia pravdu isto, verne a bez omylu ${ }^{5}$.

„12. Ked’že však vo svätom Písme Boh prehovoril prostredníctvom l'udí a l'udským spôsobom, aby vysvetl'ovatel' svätého Písma dobre pochopil, čo nám chcel Boh povedat', musí pozorne skúmat', čo vlastne mali svätopisci v úmysle vyjadrit' a čo Boh uznal za dobré prejavit' ich slovami. Aby sme zistili úmysel svätopisca, treba si okrem iného všímat' aj literárne druhy. Lebo iným spôsobom sa pravda podáva a vyjadruje $\mathrm{v}$ rozmanitých historických textoch a ináč v textoch prorockých alebo básnických, alebo v iných formách vyjadrovania. Ďalej je potrebné, aby vysvetl'ovatel' hl'adal zmysel, ktorý svätopisec chcel v daných okolnostiach vyjadrit' a skutočne vyjadril pomocou vtedy použivaných literárnych druhov, podl'a podmienok svojej doby a kultúry. Aby sa totiž správne pochopilo, čo chcel posvätný autor povedat' tým, čo napísal, treba venovat' náležitú pozornost' oným zvyčajným írečitým spôsobom myslenia, vyjadrovania a rozprávania, ktoré jestvovali v časoch svätopiscových, ako aj na spôsoby, ktoré sa v tej dobe použivali vo vzájomných l'udských stykoch. Ked’že však sväté Písmo treba čítat' a vysvetl'ovat'v tom istom Duchu, v ktorom bolo napísané, aby sa zistil pravý zmysel posvätných textov, nemenšiu pozornost' treba venovat' i obsahu a jednote

\footnotetext{
${ }^{5}$ Porov. ibid., s. 550.
} 
celého Písma a brat' zretel' na živú tradíciu celej Cirkvi a na analógiu viery. Je úlohou exegétov pričinit' sa podl'a týchto smerníc o dôkladnejšie pochopenie a vysvetl'ovanie svätého Písma, aby akosi na základe predchádzajúcich výskumov dozrelo rozhodnutie Cirkvi. Lebo všetko, čo sa týka vysvetl'ovania svätého Písma, podlieha konečnému dobrozdaniu Cirkvi, ktorá má od Boha poverenie a úlohu uchovávat' a vysvetl'ovat' slovo Božie“.

V inojazyčných prekladoch má tento bod názov: „Ako vykladat' Sväté písmo" "6. Kým sa v predchádzajúcom bode kapitoly o inšpirácii hovorilo o vzt'ahu Boha a svätopisca - možno povedat', že sa hovorilo o „systéme“ či „fungovaní“ inšpirácie v svätopiscovi - v 12. bode badat' istý posun smerom k vzt'ahu svätopisec a jeho vyjadrenie v texte a takisto aj vzt'ah čitatel', resp. interprét a napísaný text. V tomto článku je použitých niekol'ko kl'účových slov, ktoré prezrádzajú zámer jeho tvorcov: literárne druhy, podmienky doby a kultúry, Duch Svätý v procese vysvetl'ovania Písma, kontext celého Písma, interpretačná tradícia Cirkvi a analógia viery, úloha exegétov, dozrievanie rozhodnutia Cirkvi, a iné.

Ide teda o kategórie, ktoré sú súčast'ou historicko-kritickej metódy a hermeneutiky. Text sa výslovne zmieňuje o historickom zmysle textov, z ktorého treba vychádzat' pri ich vysvetl'ovaní, d'alej sa zmieňuje o dobrom poznaní vitálneho prostredia (Sitz im Leben) biblických textov, o dobrom rozpracovaní hermeneutických zmyslov a nakoniec o účasti či pomoci Ducha Svätého ako aj o jednote s celou Cirkvou pri výklade textov (posúdenie Cirkvi, analógia viery, tradícia výkladu). podstatný je teda úmysel autora. Koncil sa tu dištancuje od doslovného chápania textu a viaže neomylnost' charakterizovanú v článku 11 na úmysel l'udského autora, resp. na Božiu výpoved' v l'udských slovách svätopisca. Ak by sme sa obmedzili len na úmysel svätopisca, okamžite môže vyvstat' otázka: či je v Písme vyjadrená len taká pravda, ktorú l'udský autor pochopil a vyjadril? Nebolo to pre Boha obmedzujúce, ak mohol chciet', aby tam bolo vyjadrené iba to, čo mohol vtedy pochopit' svätopisec? Na rozriešenie týchto otázok bol definovaný sensus plenior, iní autori sa pokúšali definovat' tzv. sensus divinus $\mathrm{v}$ tom zmysle, že ide o sensus divinus in senso humano a v sensus plenior zas formulovali akúsi implicitnú otvorenost' l'udského autora pre plnost' dejín spásy v rámci napíňania Božieho plánu spásy.

Zaujímavá je téma komunitárneho rozmeru inšpirácie, ktorá bola v čase koncilu najmä medzi teológmi pomerne živo diskutovaná. Priestor preň vidíme aj v texte vo formuláciách: podl'a podmienok svojej doby a kultúry a spôsoby, ktoré sa v tej dobe používali vo vzájomných l'udských stykoch ako

\footnotetext{
${ }^{6}$ Český preklad konštitúcie Dei Verbum uverejnený na internetových stránkach Vatikánu: www.vatican.va/archivio.
} 
aj zretel' na živú tradíciu celej Cirkvi a na analógiu viery. Najvýraznejšie postrehy v tejto téme preukázal Karl Rahner, P. Benoit a P. Grelot ${ }^{7}$. K. Rahner predstavil svoju teóriu tak, že proces vzniku svätých kníh zasadil do ekleziologického kontextu s tým, že Boha chápe ako pôvodcu a svätopisca ako literárneho autora (zostavovatel'a) kníh Písma. Pri všetkej sile tejto teórie je však do značnej miery redukovaná charizmatická výnimočnost' l'udského autora. Teda inšpirovaný autor nie je jednoduchý a riadny pracovník Cirkvi, ktorý opisuje jej vieru, ale mimoriadne obdarený, Bohom vyvolený jedinec, ktorý zapíše všetko to a len to, čo Boh chce, aby bolo zapísané a Cirkvi odovzdané. P. Benoit a P. Grelot sa pokúšali predstavit' charizmu inšpirácie ako pokračovanie inej funkčnej charizmy ako napr. prorockej alebo apoštolskej charizmy, ktorú svätopisci realizovali tým, že uplatnili zas charizmu inšpirácie. Takto sa podl'a nich uskutočňoval ekleziálny rozmer tejto charizmy. Na okraj tých mienok treba povedat', že zostávajú na úrovni hypotéz a istého spestrenia náuky o inšpirácii.

„13. Vo svätom Písme sa teda prejavuje - bez akéhokol'vek narušenia Božej pravdivosti a svätosti - podivuhodná blahosklonnost' večnej Múdrosti, „aby sme sa naučili poznávat' nevýslovnú láskavost' Božiu, ako aj to, do akej miery prispôsobil Boh svoju reč vo svojej prozretel'nej starostlivosti o našu prirodzenost'. Lebo Božie slová vyjadrené l’udskými jazykmi sa pripodobnili l'udskému spôsobu hovorenia, ako ked' sa svojho času Slovo večného Otca pripodobnilo l'ud'om, vezmúc na seba krehké l'udské telo“.

Celý 13. článok našej konštitúcie možno nazvat' vel'kolepou oslavou tej blahosklonnosti Boha, ktorá sa už od čias cirkevných otcov označovala gréckym výrazom synkatábasis. Tento článok prináša teologickú explikáciu tohto výrazu, ktorý požíval už kňaz Origenes a potom ho rozvinul svätý Ján Chryzostom $^{8}$. Výraz synkatabasis (lat. condescensio) možno preložit' ako zostupovanie. Ide o poukázanie na to, že Boh „vzal na vedomie“ spôsob myslenia a vyjadrovania sa človeka, prispôsobil sa mu, znížil sa k človeku, aby jemu vlastným spôsobom (slovami, rétorickými figúrami, obrazmi, činmi) zjavil seba samého. Pritom nie je nijako redukovaná ani Božia pravdivost', ani svätost'. Božie slová sa však netransformovali na čisto l'udské slová, ale si ponechali svoj božský rozmer a ten sa k nám dostáva cez l'udské slovo svätopisca.

V druhej časti tohto článku možno nájst' - opät' patristický - koncept vel'kého teologického významu, a síce analógiu Verbum Dei incarnatum - Verbum Dei scriptum. Prvým, kto sa snažil objasnit' vzt'ah medzi týmito kategóriami, bol opät' Origenes (†254) a v posledných časoch pápež Pius

\footnotetext{
${ }^{7}$ Porov. M. TÁbet, P. Gironi, Introduzione generale alla Sacra Scrittura, op. cit., s. 36-38.

${ }^{8}$ Porov. ibid., s. 18.
} 
XII. v encyklike Divino afflante Spiritu (EB 559). Vzt'ah vteleného a písaného Slova je nádherne formulovaný pomocou biblických formulácií o Ježišovi Kristovi, ktorý sa stal človekom a bol mu podobný vo všetkom okrem hriechu, tak aj Božie slovo prijalo l'udskú či materiálnu formu vo všetkom okrem omylu ${ }^{9}$. Vieme, že kristologické a trinitárne bludy prvého tisícročia (doketizmus, arianizmus, adopcianizmus, nestorianizmus, monofyzitizmus, gnosticizmus) sa snažili svoje teórie preniest' aj na Písmo. Analógia Verbum Dei incarnatum - Verbum Dei scriptum je dostatočne jasným vysvetlením týchto problémov.

Ak by sme teda hl'adali odpoved' na celkom praktickú otázku: V čom to je, že Písmo je inou knihou ako všetky ostatné? - možno odpovedat' práve poukázaním na koncept inkarnácie, ktorý rozvinula patristika: podobne ako v Ježišovi Kristovi sa spojila božská a l'udská prirodzenost' nezmiešane a neoddelitel'ne, tak aj v Písme sa stretáva Božie slovo s l'udsky vyjadreným - napísaným slovom. Z toho možno v ktoromkol'vek čase čerpat' pravdu, ktorú tam chcel mat' Boh vyjadrenú na naše spasenie (porov. DV 11).

\section{Záver}

Vieroučná konštitúcia je vynikajúcim nástrojom oživenia spirituality dnešného človeka, pretože predstavila najvlastnejšie t'ažiská viery v Boha v personálnom svetle: Božie zjavenie, Tradícia a inšpirácia. Ich teologické pochopenie aplikovala na Starý aj na Nový zákon a 6. kapitola konštitúcie predstavuje praktický priestor pre život veriacich. Kapitola o inšpirácii nás bližšie posúva $\mathrm{k}$ náboženskej skúsenosti Božej prítomnosti v našom každodennom používaní Písma a pomáha nám tak lepšie pochopit' aký vel'ký je ten dar, ktorý máme vo Svätom písme.

Ružomberok

KS. ANTON TYROL

\section{Streszczenie}

Natchnienie Pisma Świętego. Komentarz do III rozdz. Dei Verbum

Konstytucja dogmatyczna Dei Verbum jest doskonałą pomocą do ożywienia duchowości współczesnego człowieka, ponieważ w najwłaściwszy sposób ukazuje problemy wiary w wymiarze personalnym: Objawienie Boże, Tradycję i Boskie natchnienie. Ich zrozumienie teologiczne przeniosła na Stary i Nowy Testament, a rozdział VI konstytucji przedstawia praktyczne uwagi dla życia wierzących. Rozdział o Boskim natchnieniu ułatwia nam głębsze przeżywanie Bożej obecności w codziennym korzystaniu z Pisma Świętego. W ten sposób pomaga nam lepiej zrozumieć wielkość daru, jakim jest dla nas Pismo Święte.

\footnotetext{
${ }^{9}$ Porov. ibid., s. 18-19.
} 